\title{
Comparative Trial on Biological Contact Oxidation and Bio-filter Process for Wastewater Treatment
}

\author{
Shan-Quan JIANGa ${ }^{a}$, Xiang-Wei SUN ${ }^{*}$, Li-Xing LING, Chun-Yan ZHONG, \\ Yue HU, Shi-Hong CHENG,Wu-Feng WU
}

Chongqing Key Laboratory of Environment \& Materials Remediation, Chongqing University of Art and Sciences, Chongqing 402160, China

ajiangshange@163.com

${ }^{*}$ Corresponding author

Keywords: Biofilm, Biological Contact Oxidation, Biofilter, Organic Loading.

\begin{abstract}
When domestic wastewater was treated by biological contact oxidation on soft packer and Bio-Filter process, the removal effects of $\mathrm{COD} / \mathrm{TN} / \mathrm{NH}_{3}-\mathrm{N}$ and $\mathrm{TP}$ were discussed at different $\mathrm{C} / \mathrm{N}$ and loading in the paper. Further more the combined processing of biological contact oxidation and Bio-Filter were studied. The results showed that at low loading, biological contact oxidation posed treatment efficiency, Bio-Filter process need lower energy during their COD removal rate at $80 \%$. The combined process showed merits, the COD and NH3-N removal rate of the system stabilizing at above $80 \%$ and $65 \%$ in $60 \mathrm{~d}$.
\end{abstract}

\section{Introduction}

Biological contact oxidation process and biological aerated filter are two common methods for the treatment of sewage sludge. In recent years, the structure and operating conditions of all kinds of biological membrane method using soft filler are similar to the biological aerated filter, which is widely used in simultaneous removal of COD and ammonia nitrogen ${ }^{[1]-[2]}$. The study on nitrification and phosphorus removal ability of biological membrane method has become a hot spot. But this kind of high aeration biofilm is weaknesses; Biological aerated filter is a classical treatment sewage biological reactor, it is based on the principles of soil self purification as the basis, in the sewage irrigation on the basis of practice, the more primitive intermittent sand filter and contact tank and the development of artificial biological processing technology, Because of its high efficiency and energy saving, the biological filter has been widely used in practice ${ }^{[3]-[4]}$, however, the organic loading of the common biological filter is low, and it is easy to be blocked, which limits the application range. In order to improve the organic load and save energy, it is a good choice to use two kinds of biological membrane method.

This experiment used the self-made laboratory scale device of biological contact oxidation and biological aerated filter properties of simulated wastewater. In the same load and environment, contrasting the two removals of COD, ammonia nitrogen and phosphorus removal capacity, and the study of the two series of process parameters and treatment effect of wastewater treatment.

\section{Experimental Set-up and Operation}

The experimental apparatus is shown in Figure 1.Two reactors with the same size are made of organic glass, and the height of each reactor is $1600 \mathrm{~mm}$, the effective filling height is $2000 \mathrm{~mm}$, the inner diameter is $200 \mathrm{~mm}$. The second reactor is a biological contact oxidation device; the glass column is built in light weight, fiber and soft filler. The second reactor biological aerated filter, the diameter is $3 \sim 5 \mathrm{~cm}$ ball type plastic packing, at the bottom of the $200 \mathrm{~mm}$ high supporting layer of gravel, each reactor effective filling volume 60L.Biological contact oxidation reaction from the bottom aeration, water, back flush, the upper end of the water. Two reactors can be used alone can also be used in series. When used together, the first reactor (biological contact oxidation) of the effluent as the second reactor (BAF) water. The continuous operation of $24 \mathrm{~h}$, measured daily water inlet and outlet COD, ammonia nitrogen, nitrate nitrogen. 


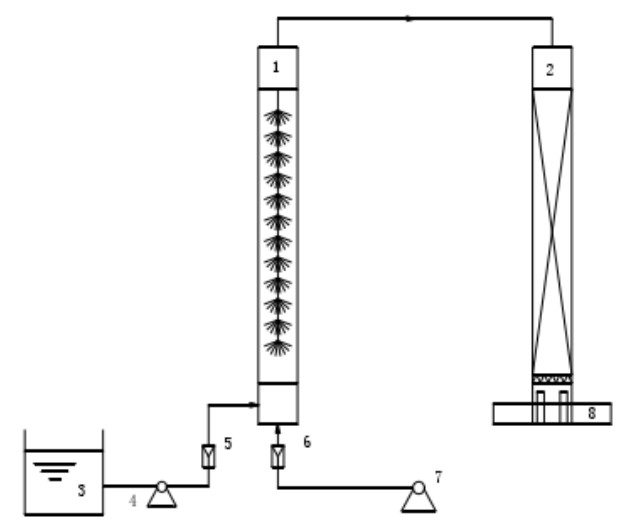

Fig.1 Biological Contact Oxidation and Biological Aerated Filter Combined Process (1.Biological Contact Oxidation Reactor; 2.Bio Filter; 3.Into The Water Tank; 4.Water Pump; 5.Water Pump Meter; 6.Aeration Pump Flowmeter; 7.Aeration Pump; 8.Biological Filter Tank)

\section{Experimental Samples}

The basic raw material: Powdered Milk, $\mathrm{NH}_{4} \mathrm{Cl}, \mathrm{NaHCO}_{3}, \mathrm{KH}_{2} \mathrm{PO}_{4}, \mathrm{~K}_{2} \mathrm{HPO}_{4}, \mathrm{CaCl}_{2}$, $\mathrm{MgSO}_{4} \cdot 7 \mathrm{H}_{2} \mathrm{O}, \mathrm{FeCl}_{3}, \mathrm{KCl}, \mathrm{MnCl}_{2}, \mathrm{CuSO}_{4} \cdot 5 \mathrm{H}_{2} \mathrm{O}, \mathrm{ZnSO}_{4}$. The raw materials are added according to a certain proportion of sewage wastewater prepared as experimental samples, and $\mathrm{BOD}_{5} / \mathrm{COD}=0.4$ was kept. The concentration of each pollutant in the water is controlled within the range shown in Table 1.

Tab.1 Influent Composition of Sewage mg/L

\begin{tabular}{llllll}
\hline Parameter & $\mathrm{COD}$ & $\mathrm{NH}_{4}^{+}-N$ & $\mathrm{TN}$ & $\mathrm{TP}$ & $\mathrm{pH}$ \\
\hline Range & $190 \sim 580$ & $20.0 \sim 55.0$ & $30 \sim 60$ & $3.00 \sim 14.00$ & $7.14 \sim 7.78$ \\
\hline Average Value & 370 & 37.0 & 45 & 8.50 & 7.46 \\
\hline
\end{tabular}

\section{Experiment Method}

This experiment uses Upflow Biological contact oxidation, gas and water at The same direction; The down flow biofilter, the top and bottom of the water inlet, a water collecting tank, 24 hours of continuous operation; Combination technology combined with biological contact oxidation and biological contact oxidation filter effluent as biofilter inlet.

Initial contact oxidation reactor to add a certain amount of a certain amount of mud bored, The biological filter for continuous water, flow $(5 \mathrm{~L} / \mathrm{h})$, after running $30 \mathrm{~d}$, are changed to flow $10 \mathrm{~L} / \mathrm{h}$, $24 \mathrm{~h}$ continuous operation, of hydraulic load $\mathrm{q}=7.5 \mathrm{~m}^{3} / \mathrm{m}^{2} . \mathrm{d}$. With the naked eye can be observed in soft packing biofilm attached a lot of filamentous floc, plastic ring is wrapped on the surface of biofilm color gradually by grey into pale yellow, when measured to cod and removal rate reached $80 \%$ and $60 \%$ respectively, which show that the film is successful. During the whole experiment, control of $\mathrm{pH}$ is $6 \sim 9$, the flow of $10 \mathrm{~L} / \mathrm{h}$, gas water ratio of $6: 1$, reaction temperature range of $10 \sim$ $30^{\circ} \mathrm{C}$. Filter back flushing mode is water washing.

The whole experiment was first under different organic loading conditions, and the effect of contact oxidation and biological filter on COD, and TP treatment were compared and analyzed. Finally, the combined process of contact oxidation and biological filter was discussed.

\section{Analysis Method and Instrument}

Determination of potassium dichromate method COD, Instrument for the determination of type MS-3 microwave digestion instrument (Shanghai experimental instrument factory; Ammonia 
nitrogen, nitrate nitrogen, nitrite nitrogen determination method were $\mathrm{Na}$ 's reagent spectrophotometric method, phenol disulfonic acid photometric method, N - (1-naphthyl) ethylenediamine spectrophotometry ${ }^{[5]}$. Ammonia nitrogen, nitrate nitrogen and nitrite nitrogen were measured by 721 type ultraviolet visible spectrophotometer (Shanghai third analytical instrument factory).

\section{Results and Discussion}

\section{Removal of COD under Low Organic Loading}

Fig. 2 shows the low COD $\left(\mathrm{COD}=200 \sim 300 \mathrm{mg} / \mathrm{L}, \mathrm{Lv}=0.32 \sim 0.48 \mathrm{kgCOD} / \mathrm{m}^{3} . \mathrm{d}\right)$ case, the treatment effect of contact oxidation and biological filter. As can be seen from Figure 2, the COD removal rate of biological filter was gradually decreased with the increase of COD concentration. The removal rate of biological contact oxidation is slightly higher than that of biological filter, and the trend of removal rate curve is stable. The COD is less than 300, two the removal rate of COD which can reach more than $80 \%$, the effluent meet the "urban sewage treatment plant pollutant discharge standard" (GB18918-2002) level of B standard.

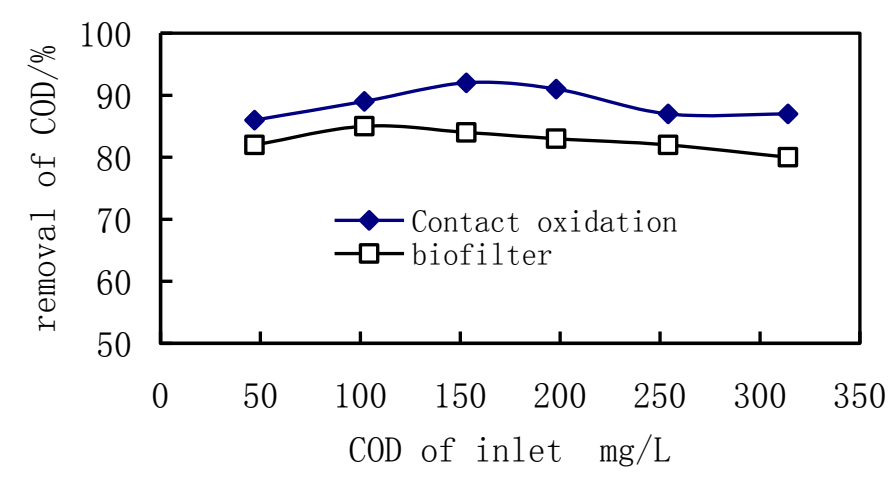

Fig.2 Removal of COD with Low Organic Loading

\section{Removal of COD under High Organic Loading}

When increasing the influent $\mathrm{COD}$ concentration $(\mathrm{COD}=300 \sim 600 \mathrm{mg} / \mathrm{L}, \mathrm{Lv}=0.48 \sim$ $\left.1.00 \mathrm{kgCOD}_{5} / \mathrm{m}^{3} . \mathrm{d}\right)$, the biological membrane and biological filter treatment effect is poor, but the two are slightly different, from figure 3 below.

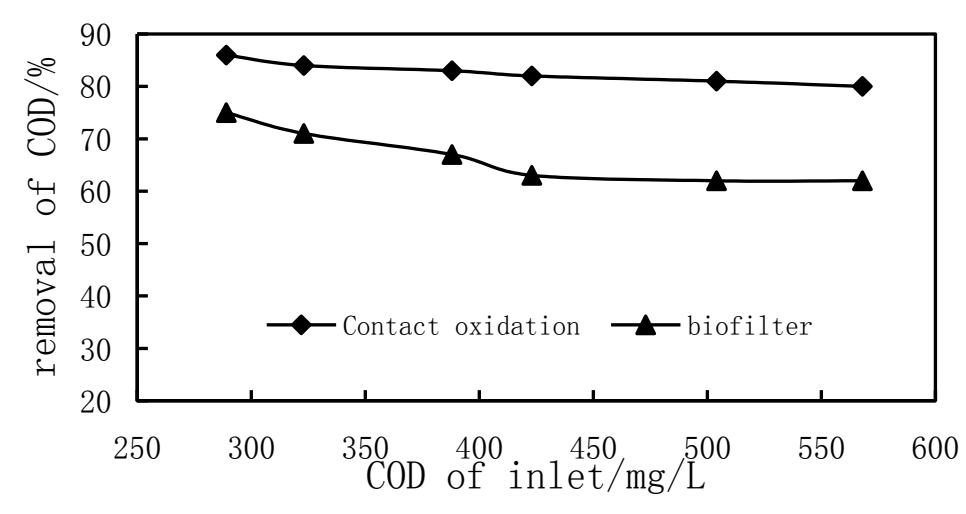

Fig.3 Removal COD of High Organic Loading

Contact oxidation removal rate of COD decreased with the increase of COD, stable at $70 \%$ $80 \%$. The biofilter removal rate of COD decreased significantly in COD, more than $300 \mathrm{mg} / \mathrm{L}$, the removal rate of COD is less than $70 \% \mathrm{COD}$, equal to $600 \mathrm{mg} / \mathrm{L}$, the removal rate of COD to $60 \%$. 
The organic loading rate of common biological filter is relatively low compared with the contact oxidation reactor $\mathrm{NH}_{3}-\mathrm{N}$.

\section{Comparison of Nitrogen Removal Efficiency}

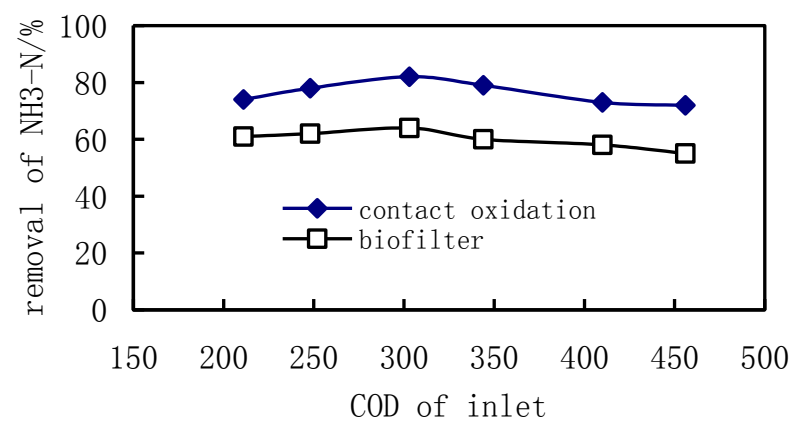

Fig.4 Comparison Removal $\mathrm{NH}_{3}-\mathrm{N}$ of Biological Contact Oxidation and Biological Filter

Control of influent $\mathrm{C} / \mathrm{N}$ ratio $5 \sim 8$, and gradually increase the organic load, in the COD less than $250 \mathrm{mg} / \mathrm{L}$, removal rate is greater than $80 \%$, when the COD is greater than $250 \mathrm{mg} / \mathrm{L}$, the removal rate decreased, the effluent concentration is difficult to reach $15 \mathrm{mg} / \mathrm{L}$. This is mainly due to the heterotrophic bacteria specific growth rate than autotrophic nitrifying bacteria high, so organic loading increased the nitrifying bacteria was inhibited, thus affecting the reactor on the removal effect of ${ }^{[6]}$. From the figure that biological contact oxidation removal rate is slightly better than the filter. The DO of biological contact oxidation reactor has a certain effect on nitrification. The biological film has the environment of nitrogen removal, according to the mechanism of nitrogen removal, the first nitration, and then denitrification in the presence of carbon source. Biofilm sludge is deep and long sludge age, and has a wide range of denitrification micro environment, but nitrification is often behind the removal of COD, organic loading increased, DO decreased, so that the nitrification lag. Biofilm process disadvantage is in maintaining higher nitrification effect are required higher dissolved oxygen ${ }^{[7]}$, which is removal effect of nitrogen variable difference of important reasons.

\section{Dephosphorization Effect Analysis}

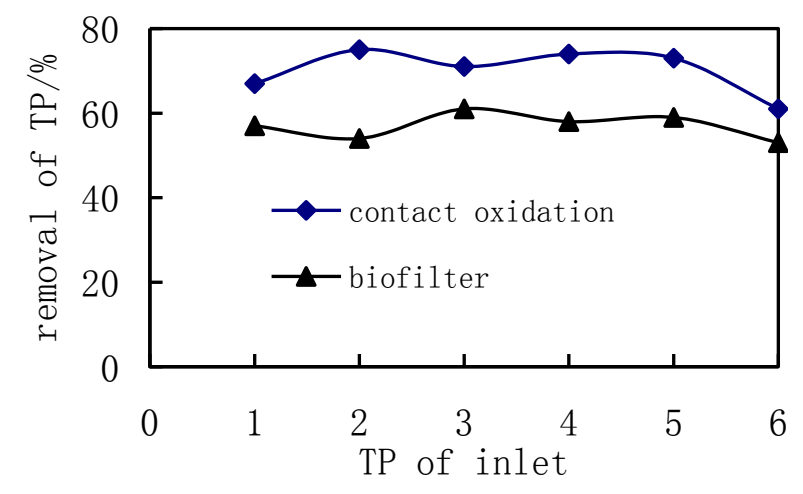

Fig.5 Removal TP of Biological Contact Oxidation and Biological Filter

Biofilm characteristics is large biomass, there is a widespread anaerobic area and a good oxygen area $^{[8] \sim[9]}$, with removal of the objective environment, but all kinds of biological film process sludge age longer, is not conducive to the accumulation of phosphorus bacteria growth, limiting biofilm process for phosphorus removal effect. Control the influent COD for $200 \mathrm{mg} / \mathrm{L}$, change the TP concentration, and make the TP removal curve. From Fig.5, we can know that the phosphorus removal rate is $80 \% \sim 60 \%$, when the influent TP is greater than $5 \mathrm{mg} / \mathrm{L}$, the effluent $\mathrm{TP}$ is greater 
than $1 \mathrm{mg} / \mathrm{L}$.In addition, from Figure 4 it was found that the biological contact oxidation process is better than biological filter. The removal rate of biological contact oxidation reactor is slightly higher than that of biological filter; the reason may be that when the other conditions are the same, the hydraulic retention time of the biological contact oxidation reactor is greater than that of the biological filter.

\section{Effect Analysis of Combined Process Treatment}

The biological contact oxidation and biological aerated filter combination, namely, biological contact oxidation is a grade two class of biological filter. Biofilm gas water ratio of 3:1, to improve the influent COD and concentration, COD for $300 \sim 600 \mathrm{mg} / \mathrm{L}, 40.8 \sim 70.5 \mathrm{mg} / \mathrm{L}$, the treatment effect is shown in Figure 10 and figure 11.The figure shows that the biological contact oxidation reactor and bio-filter combination of COD and the removal rate in $80 \%, 65 \%$, the effluent COD concentration and reached the urban sewage treatment plant pollutant discharge standard: (GB18918-2002) First level A standard.

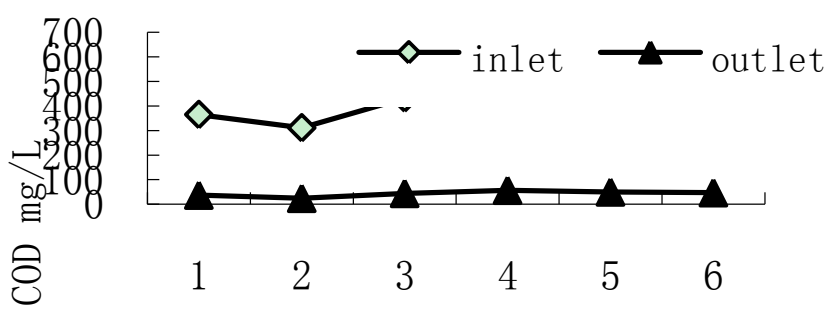

Fig.6 Combined Process for Removal of COD

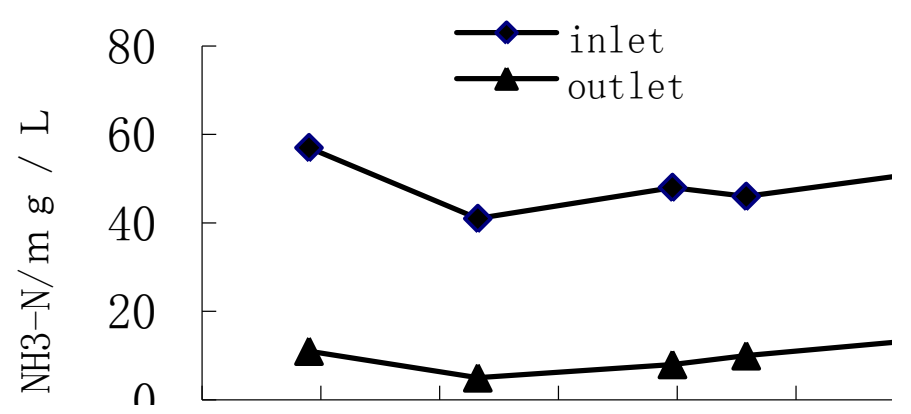

Fig.7 Combined Process for Removal $\mathrm{NH}_{4}^{+}-\mathrm{N}$

The combination process greatly prolongs the residence time of wastewater in the reactor, which is the main reason for improving the treatment effect.

As the biological membrane effluent is a filter inlet, the biological contact oxidation device takes up the flow type water, while the filter takes the down flow type, forms the internal water circulation, and saves the energy of the waste water promotion.

There are two methods to improve the treatment effect of biological contact oxidation reactor, one is to improve the gas / water ratio; two, increase the biofilm biomass, but the biofilm thickness increases, and the transport efficiency of the reduced oxygen ${ }^{[10]-[11]}$. But above two measures will inevitably lead to the increase of the amount of aeration, increase energy consumption.

There are two methods to improve the treatment effect of filter too. One is to improve the reflux ratio, and the other is to increase the biomass. The same reflux ratio of the increase, is bound to increase energy consumption, and biomass is too much may be generated anaerobic dead angle, the impact of the processing function ${ }^{[12]}$.

Combined process of clever use of the structural characteristics of biological contact oxidation and biological aerated filter, without increasing the additional energy consumption, increasing 
process and prolong the residence time, the formation of secondary system, COD, are fully degradable.

\section{Conclusion}

(1) When the temperature of the water for 15 to 30 DEG C, gas water ratio is $6: 1$, the influent COD and concentration were $200 \sim 363 \mathrm{mg} / \mathrm{L}$ and $16-8 \sim 31$, 3mg / L conditions, biological contact oxidation and biological aerated filter for sewage treatment with good purification effect. Its effluent COD reached the "urban sewage treatment plant pollutant discharge standard" (GB18918-2002) (GB18918-2002) First level A standard.

(2) The effect of biological contact oxidation on TP treatment is better than that of biological filter. Increase the organic load to reduce the effect of biological contact oxidation reactor and bio filter treatment, especially the biological aerated filter is more obvious, that the traditional biological contact oxidation and biological aerated filter if it doesn't improve aeration and recirculation ratio is difficult to raise treatment efficiency.

(3) Of a liter of biological contact oxidation and biological aerated filter combined process flow is greatly prolonged residence time, the relative energy saving, in a low water ratio: $3: 1$, high organic concentration $(\mathrm{BOD}=300 \sim 600 \mathrm{mg} / \mathrm{L}$ ) case, the ideal processing effect, and COD removal rate was stable at $80 \%, 65 \%$ above.

\section{References}

[1] Jiang R, Huang S B, Yang J. Biological removal of NOx from simulated flue gas in an aerobic biofilter [J]. Global Nest Journal. 2008, 10(2): 240-247.

[2] Hong-Duck R, Daekeun D, Heun K,etal. 2008. Nitrogen removal of low carbon/nitrogen wastewater with four-stage biological aerated filter system [J]. Process Biochemistry, 43(7): 729 735.

[3] GUO Junyuan, YANG Chunping, ZENG Longyun, HE Huijun, DENG Zhengyu. Influence of reflux ratio and hydraulic loading on the performance of pre-denitrification BAF in wastewater treatment [J]. Acta Scientiae Circumstantiae. 2010, 30(8):1615 1621.

[4] LIU Yu-Bing, WANG Xiao-jun.Application of integrated process of ozone-biological aerated filter and up-flow biological aerated filter for advanced treatment of tannery wastewater [J]. Modern Chemical Industry. 2012, 32(8):72 74.

[5] The State Environmental Protection Administration Committee of shui he feishui jianche fenxi fangfa. shui he feishui jianche fenxi fangfa [M]. Beijing: China Environmental Science Press, 2002.

[6] Noophan P (Lek), Sripiboon S, Damrongsri M,et al.Anaerobic ammonium oxidation by Nitrosomonas spp. And anammox bacteria in a sequencing batch reactor [J]. Journal of Environmental Management, 2008:1-6.

[7] Jin Ren-Cun, Zheng Ping. Kinetics of nitrogen in hight rateanammox up-flow filter[J] . Journal of Hazardous Materials, 2009:1-4.

[8] YOOH, AHN K H, LEE H J. Nitrogen removal from synthetic wastewater by simultaneous nitrification and denitrification (SND) via nitrite in an intermittently-aerated reactor [J]. Water Res, 2009, 33(1):145-154.

[9] SUN Ying-Xue, XU Dong, TIAN Yuan, LI Yan-fei. Mechanism of Nitrogen Removal by partial Nitrification-Denitrification Biological filter [J].environmental science, 2012, 33(10):3501-3506.

[10] JIANG Shan-quan, ZHAI Jun, XIAO Hai-wen, ZHENG Ze-gen. Study on Simultaneous Biological Nitrogen and Phosphorus Removal in New Sequencing Batch Biofilm Reactor System [J]. JOURNAL OF SICHUANUNIVERSITY (ENGINEERING SCIENCE EDITION). 2008, 40(1): 
64 68.

[11] XING Mei-yan, YANG Jian, MA Xiao-jie. Study on Nitrification Performance of Vermi biofilter and Its Influencing Factors [J]. CHINA WATER \& WASTEWATER, 2008, 24 (3):9 12.

[12] WANG Yong-cai, CHEN Wei, ZHENG Xiao-ying, HUANG Wei-li, SUN Jun. Influencing Factors of Simultaneous Nitrification and Denitrification in Biological Contact Oxidation Process [J]. CHINA WATER \& WASTEWATER. 2011, 27(7):22 25. 